\title{
LIMITATIONS OF THE FREEDOM OF SPEECH IN THE INTERNET
}

\begin{abstract}
The development of Internet services lead to many changes in forms of expression of our opinions and ideas. The author shall discuss whether the term "freedom of speech" is still suitable for modern times, regarding the conversations in the social media. As we all know, the freedom of speech and the freedom of expression were never absolute and certain limitations of them are completely legal and necessary. However, as the author will try to prove, there are some serious concerns about executing such limitations online as well as effectively proving if someone's rights have been violated due to excess of freedom of expression. The possible ideas of fighting the hate speech and other acts of trespassing the right to free expression shall also be presented.
\end{abstract}

Keywords: freedom of speech, freedom of expression, Internet, social media, limitations.

Ograniczenia wolności słowa w Internecie Rozwój usług Internetowych spowodował wiele zmian w sposobach wyrażania naszych opinii i pomysłów. Autor przeprowadzi rozważania odnośnie tego czy określenie "wolność słowa" jest wciąż adekwatne do współczesnych czasów, odnosząc się do rozmów w przestrzeni mediów społecznościowych. Powszechnie wiadomo, że wolność słowa i wolność wypowiedzi nigdy nie były absolutne i pewne ich ograniczenia są całkowicie legalne oraz konieczne. Jednakże, jak autor spróbuje wykazać, istnieją poważne wątpliwości odnośnie wykonalności takich ograniczeń w sieci, a także efektywnego dowodzenia, że cudze prawa zostały naruszone w związku z przekroczeniem granic wolności wypowiedzi. Propozycje możliwych rozwiązań w walce z mową nienawiści i innymi przejawami przekraczania prawa do wolności wypowiedzi także zostaną zaprezentowane.

Słowa kluczowe: wolność słowa, wolność wypowiedzi, Internet, media społecznościowe, ograniczenia.

The turn of XXth and the XXIst century was a start of the new era in interpersonal relationships. The major role of the Information Society in the modern world has become a true trendsetter for the way we communicate with the others. With every passing year since 1991, when the World Wide Web became publicly available, more and more people started

\footnotetext{
${ }^{1}$ Bartosz Brzyski - Faculty of Law and Administration, Nicolaus Copernicus University in Torun.
} 
to share their ideas and statements online instead of doing the same in person. That lead firstly to the promotion of using the e-mail as a faster and more convenient substitute for post, and later on to the development of Facebook in 2004, Twitter in 2006, Instagram in 2010 and many more online services allowing the society to replace, at least partially, our previous habits. Currently different types of social media play the metaphorical role of the ancient Forum Romanum - the role of a place where the most important discussions happen. Of course, that does not mean all the conversations and public debates seized to exist in real life, however such transformation gave people access to plenty of new benefits unknown to the conventional way of conversing with the others. Those advantages such as ease of reaching the greater audience with the message, instant replies or the opportunities to visualize any idea, were not possible before for almost everyone in their day to day lives. At the same time, previous inventions which offered less complex services such as SMS or MMS messages, started to fade being replaced by better alternatives online. This change was not made so commonly only because of the popularity of the social media, in fact it was made out of necessity. These days, it is hard to imagine running a worldwide business or preparing educational projects in multinational teams without using different types of social communicators. The need to stay in touch with different people somehow forces more and more users to begin using social media. According to statistics, the number of social media users worldwide is constantly growing, since in 2010 it reached about 0.97 billion of people whereas it is forecasted that in 2021 it will reach 3.09 billion users. ${ }^{2}$ The importance of changing the way we converse from face to face communicates to online posts is significantly visible especially right now. Since WHO announced COVID-19 outbreak a pandemic $^{3}$, almost every highly developed country forced their citizens to stay at home. Such decision could not have been made ever before, because the technological barriers of limited access to the Internet were restraining the amount of possible actions to take by the governments. Right now they can provide teaching in the form of the e-learning and keep in touch with millions citizens by sending fast messages, while receiving instant feedback something that television could never possibly offer. And that phenomenon of bringing more and more activities online should be worrying. Not only because of the argument that people

\footnotetext{
2 Number of social media users worldwide from 2010 to 2021, Statista - The statistic portal, https://www.statista.com/statistics/278414/number-of-worldwide-social-network-users/ [access: 28.03.2020]. ${ }^{3}$ WHO announces COVID-19 outbreak a pandemic, World Health Organization Regional Office for Europe, http://www.euro.who.int/en/health-topics/health-emergencies/coronavirus-covid-19/news/news/2020/3/whoannounces-covid-19-outbreak-a-pandemic [access: 28.03.2020].
} 
shall lose their humanity by creating the virtual reality, but also because the Internet, thereby social media, remains legally unregulated in many ways.

That matter concerns most branches of law, however when discussing the social media it is worth focusing on the one specific right, classified as one of the most important constitutional freedoms in the civilized countries - the freedom of speech. It is natural that this very aspect of the modern legal systems remains a problematic topic, because the Internet is a place where people, as said before, are constantly sharing messages and opinions, and the social media are basically made to allow them to converse all the time. That leads to many questions, which despite the passage of time, still have no undisputable answers. Those can be for example:

- does everyone in the Internet have the right to speak freely?

- should any national laws regarding the freedom of speech apply to the Internet users?

- can private companies act as self-called judges in terms of limiting the freedom of speech in their online services?

First of all, we shall define what the "freedom of speech" is. Probably most of us should be able to reconstruct the proper definition by intuition. In my opinion the freedom of speech is the right to orally share any ideas, statements or messages without any kinds of pressure or repression from any third parties. However, if we look at the legal acts we will see that such term barely appears. One of the acts which uses the term "freedom of speech" actually dates back to 1689. That act is the English Bill of Rights ${ }^{4}$, and such phrase is placed in its ninth article which states: "that the freedom of speech and debates or proceedings in Parliament ought not to be impeached or questioned in any court or place out of Parliament”. Another act in which we can find this phenomenon is the United States Constitution, exactly in its first Amendment from 1791 to be precise, where we can read that "Congress shall make no law respecting an establishment of religion, or prohibiting the free exercise thereof; or abridging the freedom of speech, or of the press; (...)”. However, following the later legislation in many countries this term starts to disappear. The article 10 of the ECHR uses the term "freedom of expression" instead of "freedom of speech". So is the ICCPR in the article 19.2., which at the first sight is simply a more complex definition of the ECHR statement. Also Polish Constitution in the article 54., in its official English translation published on the Polish Sejm's website states that “The freedom to express opinions, to

4 Bill of Rights, 1689, http://www.legislation.gov.uk/aep/WillandMarSess2/1/2/introduction [access: 28.03.2020]. 
acquire and to disseminate information shall be ensured to everyone.”, avoiding the term "freedom of speech". Some may say that it is just a change of the word and both terms should be used synonymously, however in my opinion it is not. Focusing on the literal interpretation, the Cambridge English Dictionary defines "expression" ${ }^{5}$ " as "the act of saying what you think or showing how you feel using words or actions", while the "speech" described as "the ability to talk, the activity of talking, or a piece of spoken language”. As we see then, while the "speech" focuses on the oral way of sharing the information, the "expression” also allows this to happen in other non-oral actions. Coming back to the mentioned article from ICCPR, it is worth presenting its content in full, which is: "19. 2. Everyone shall have the right to freedom of expression; this right shall include freedom to seek, receive and impart information and ideas of all kinds, regardless of frontiers, either orally, in writing or in print, in the form of art, or through any other media of his choice.”. As we see here, freedom of expression includes far more elements than just the right to speak freely. It contains more than just the right to create and express an opinion, but also to seek and receive such in any way, which in fact is the main foundation of the Internet - the place of sharing and searching for the information. Proceeding further, this term includes not only the right to share oral messages without any kinds of pressure, but also - as it is written - it is the freedom of sharing expressions through prints, art or any other media. That may lead to a conclusion that the phrase "freedom of expression" is a way wider term then the "freedom of speech", and thereby the "freedom of speech" is a component part of the "freedom of expression". This term is definitely more suitable for modern times, because it predicts all possible scenarios of sharing an opinion, not only orally, which in the day of the Internet and social media is a constantly growing catalogue. Thus, for example, in the the context of Polish Constitution we shall agree with P. Tuleja that "the freedom to express opinions” from article 54. includes expressions of opinions and convictions in all possible forms, not only in the oral form but also in a different way, including expressions published in the Internet or social media ${ }^{7}$. However, I disagree with his terminology as he also says that the "freedom of speech" is so called the "freedom of expression", because these two terms literally interpreted differ from each other and are not synonyms, and because of that they may be used in different contexts. In my opinion the freedom of speech is limited only

\footnotetext{
${ }^{5}$ Cambridge Dictionary, https://dictionary.cambridge.org/dictionary/english/expression [access: 28.03.2020].

${ }^{6}$ Ibidem.

${ }^{7}$ P. Tuleja (red.), Konstytucja Rzeczypospolitej Polskiej. Komentarz, Warszawa 2019.
} 
to oral communicates whereas the freedom of expression contains all possible actions of sharing messages. That is why the term freedom of speech should be used as a very specific classification or as a common name, but certainly not as a synonym. In the light of the arguments listed above, for the rest of this article I would like to use the term freedom of expression, as from my point of view it is more suitable according to the messages published in the Internet.

Now when we know what the freedom of expression is, we shall discuss whether it applies to the Internet users or why not. Currently no country can call itself "the owner of the Internet”. Many people believe that it is the United States of America who rules the Internet, but in fact it is neither true nor possible. Of course the Internet has its roots mostly on the American continent, however it is nothing more than just a tremendous number of linked computers sharing data around the whole world. And that brings us to the problem of possible conflicts of law. We cannot say that any national law completely regulates the Internet space, however some of the national regulations may affect certain aspects of online life. Nevertheless in the matter of freedom of expression that should not be the case. We do not have to prove that it derives from any national constitutional guarantees of such freedom, since most of existing countries ratified the ICCPR, which as it was discussed before, recognizes it as a human right. That leads to the conclusion that we can treat online freedom of expression as a universal value, not bound to any national jurisdiction, and it should apply automatically to any Internet user. Of course we can discuss what happens with the citizens of countries which somehow do not provide the right to free expression in any way, but the truth is that in the terms of the Internet the only way they could possibly execute such strict censorship is to ban the Internet at all or at least close the network strictly inside its own borders. However, not every limitation of this freedom must be the absolute ban. The case becomes complicated when we think about partial limitations of freedom of expression. As we all know some of these are completely legal, since the unlimited use of this right may lead to endangering most important values such as: health, safety or reputation. The criteria that determine the legality of such limitations are written both in the ICCPR (Article 19.3) or ECHR (Article 10.2). Additionally we can read in the Council of Europe's factsheet about ECHR's Article 10, that The Court has stressed the constitutional importance of this article and said interference can be justified only by imperative necessities and exceptions must be 
interpreted narrowly ${ }^{8}$. Following the words of one of the Polish Supreme Court's judges "Freedom of speech cannot be a panacea for everything, freedom of speech is not absolute, freedom of speech does not allow to write everything. It is also limited by the rights of other

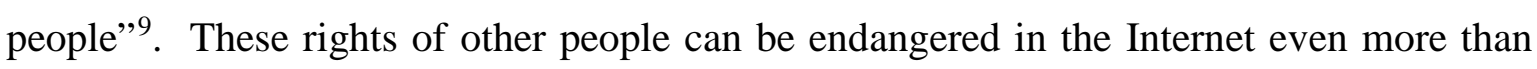
anywhere else. That is because as it was said before, the Internet offers a possibility to reach a massive audience, and thereby unlawful actions can cause serious damage . That makes any leak of confidential information, spread of pornography or acts of hate speech and incitement etc., much more dangerous than ever before. Naturally then the governments of every country wish to maintain control of certain actions taken by their citizens or aimed against their interests. That brings us to the problem of jurisdiction in cyberspace.

In social media we can encounter different actions which possess the constituting elements of hate speech, libel or slander. That is because in spite of the passage of time there is still a myth that everyone in the Internet remains anonymous. These actions cannot be left without any kind of condemnation. The amount of questionable content that is found unlawful and beyond the boundaries of freedom of expression will vary in different countries, being based on various cultural, economic or political aspects. As N. J. Reventlow rightly notes in one of the collection of esseys edited by The Berkman Klein Center for Internet \& Society at Harvard University, views on what is considered offensive or acceptable speech will inevitably change according to who is judging ${ }^{10}$. That is why certain actions in the Internet are regulated by national laws differently, and are either prohibited or allowed. As long as the law enforcement authorities lead the case of their own citizen acting against the country's interests online or acts between two citizens of their own, there should not be much of the problem - the country will probably adapt its law to the needs of the case which happened online. The problems appear when the citizen acts online from abroad where such actions may not be treated as a crime or offense, or if he acts from his home country but affects entities from abroad. According to my research there are no universal rules of specifying the jurisdiction on online actions yet. The territorial jurisdiction seems to

\footnotetext{
8 Freedom of expression - factsheet, CoE, https://rm.coe.int/CoERMPublicCommonSearchServices/DisplayDCTMContent?documentId=09000016800 7aee2 [access: 28.03.2020].

${ }^{9}$ A. Krzyżanowska, Prokuratorowi można zarzucić, że nie zna prawa. Trzeba to jednak czynić z taktem, Rzeczpospolita, 2020, https://www.rp.pl/Adwokaci/200119742-Czy-adwokat-moze-prokuratorowi-zarzucacnieznajomosc-prawa---orzeczenie-Izby-Dyscyplinarnej-SN.html [access: 28.03.2020].

${ }^{10}$ N. J. Reventlow, The Right to 'Offend, Shock or Disturb'or The Importance of Protecting Unpleasant Speech, Perspectives on Harmful Speech Online, a collection of essays, August 2017, Berkman Klein Center for Internet \& Society at Harvard University, https://dash.harvard.edu/bitstream/handle/1/33746096/201708_harmfulspeech.pdf?sequence=5\&isAllowed=y [access: 28.03.2020].
} 
be the least probable to be used. It is almost impossible to describe where the trespass of the freedom of expression happened in the social media, since the Internet is a virtual undefined space. Using the domain suffix (“.pl,”, “.uk” etc.) or the website’s hosting provider location as a point of reference can be extremely confusing since the actual entities running the service can be located in different countries. Thus the personal jurisdiction or principium reale will be dominant in determining the means of one's responsibility. The universal jurisdiction may be useful as well, but we must remember that not many crimes against humanity are directly linked with trespassing the freedom of expression. As it was stated before, different countries can have different perspectives on what is unlawful in terms of exceeding this right, and that is why in my opinion there is not a big chance of constituting universal standards of limits for this freedom, which could possibly reduce the impact of this problem.

The next topic refers to what can be done to prove that someone exceeded the freedom of expression online. Let us suppose that someone wrote a clearly controversial comment in the social media carrying the marks of libel against his friend, and that action is treated as a violation of personal rights in his country. The mentioned friend sues the creator on the grounds of civil law demanding a recompense for the loss of his reputation. According to my personal experience, in Polish reality one of the key evidence presented by the sides would be the prints of screenshots visualising a problematic comment. However, in my opinion, such evidence has no credibility. First of all, it does not require much of the technological knowledge to point how easy it is to falsify such print - in fact a precise copy/paste action on someone else's comment can make an imperceptible illusion as if it was the expression of the alleged person. Secondly, the user which is sued for libel online can always pretend that his account was hacked, or someone else gained access to it and wrote the comment in his name. The third thing is that since everyone can create the unlimited number of social media accounts and simply steal other's pictures and personal information, there is always a risk that someone created a fake identity just to post such comment and violate someone's name, and is not even present as a side during litigation. The forth argument, is that someone can delete the comment before it is saved as an evidence and that fact will almost certainly eliminate the possibility of pursuing legal consequences. That leads to a conclusion that in fact nobody else than the owner of the specific social media service can provide a credible evidence about the true content, shape and author of such comment - of course if it is only saved in the data banks. In most cases linked to the trespass of freedom of expression, law enforcement authorities may have a lot of trouble with finding 
the exact location from where the problematic message have been sent, and therefore with assessing who is guilty of such action. This situation sadly gives the impression that such offenses are impossible to be tracked down and the perpetrators remain unpunished.

However, there is a simpler solution than providing expensive and complicated tools for the police in terms of fighting with the hate speech and other illegal acts online. Not to mention that they would probably heavily interrupt with other personal rights. Since most significant publications online happen in the space of social media, maybe the key to effectively fight with trespassing the freedom of expression is to allow the owners of such services to set the limits for this freedom by themselves? In fact it is already happening. For example, Facebook introduced a very wide range of community standards which prohibit the publication of content clearly exceeding the fair boundaries of freedom of expression ${ }^{11}$. First of all we shall discuss if such entities as Facebook, Twitter or other social media are allowed to set their own limits in this case. Most of the services of this business are run by companies registered in the United States, thus they abide to the US legislation. Coming back to the mentioned at the beginning Amendment 1 to the US Constitution, we shall see that this regulation is addressed to the Congress, thus the governmental authorities - not to the private entities. That is why, in my opinion there are no, at least constitutional, barriers for such companies to have their own standards for freedom of expression as long as they remain reasonable and with respect for human rights. We must not forget that social media services are powerful business and marketing tools, so providing a user friendly environment and controlling the fair course of discussion is simply desirable for their developers, and that is why they try to apply different moderation rules. But are such limitations really effective? After all, as C. Tilton spotted, human moderation of online discussion sections is both timeconsuming and expensive ${ }^{12}$. We must not forget that the technological advancement still keeps going on, and the role of human moderators is supplemented by specialized algorithms and artificial intelligence. Right now the virtual scripts are able to scan the whole social media, catch the controversial publications and terminate it, eventually resulting in banning the user from the service. Such solution definitely helps to protect the cyber environment from negative content as well as helps to maintain peaceful debate online. However, these

\footnotetext{
11 Community Standards, Facebook, https:/www.facebook.com/communitystandards/objectionable_content [access: 28.03.2020].

${ }^{12}$ C. Tilton, Goodbye to Anonymity? A New Era of Online Comment Sections, Perspectives on Harmful Speech Online, a collection of essays, August 2017, Berkman Klein Center for Internet \& Society at Harvard University, https://dash.harvard.edu/bitstream/handle/1/33746096/201708_harmfulspeech.pdf?sequence=5\&isAllowed=y [access: 28.03.2020].
} 
algorithms are still imperfect and very often skip the content grossly exceeding the boundaries of a free expression while messages published as a joke or having a different meaning in the context of a conversation are repressed. And these controversies about the ineffective moderation lead to many objections from the experts. In 2018 deputy of Polish Commissioner for Human Rights S. Trociuk issued a letter where he stated that from the Commissioner's point of view, this type of action can be considered a limitation or even violation of constitutionally protected freedom ${ }^{13}$. In my opinion though, currently we have no better alternatives. That does not mean that this problem should remain undiscussed - on the contrary, I think we shall constantly propose new solutions. Social Media developers have a lot of prospects for a cooperation with local authorities in terms of protecting the freedom of expression and in terms of fighting against excesses of it. Because only they have an instant and almost unlimited access to the information about their users, I can imagine a procedure containing a suitable notification for the user with a warning of the possibility to begin legal procedures, and if the person would not stop to excess the freedom of expression the developers could secure the evidence and inform the proper legal institutions in suspected country of user's origin, which shall decide whether any offense was committed. If such notification would be completely ignored by the perpetrator, that would justify the blockade of the account as a countermeasure for toxicity in social media, however I believe that for most users such warning would result in the chilling effect. Although, in any undertaken actions it is vital not to lose the very spirit of the Internet which is independence and rather liberal approach to expressing thoughts.

\section{BIBLIOGRAPHY:}

1. Tuleja P. (ed.), Konstytucja Rzeczypospolitej Polskiej. Komentarz, Warszawa 2019.

2. Reventlow N. J., The Right to 'Offend, Shock or Disturb,' or The Importance of Protecting Unpleasant Speech, Perspectives on Harmful Speech Online, a collection of essays, Berkman Klein Center for Internet \& Society at Harvard University, August 2017.

3. Tilton C., Goodbye to Anonymity? A New Era of Online Comment Sections, Perspectives on Harmful Speech Online, a collection of essays, Berkman Klein Center for Internet \& Society at Harvard University, August 2017.

4. Trociuk S., Pismo RPO do Ministerstwa Cyfryzacji ws. praktyk portali społecznościowych, Deputy of Polish Commissioner for Human Rights, VII.562.1.2018.KD, Warsaw 2018.

5. Community Standards, Facebook, https://facebook.com.

6. Freedom of expression - factsheet, Council of Europe., https://www.coe.int.

\footnotetext{
${ }^{13}$ S. Trociuk, Pismo RPO do Ministerstwa Cyfryzacji ws. praktyk portali spolecznościowych, Deputy of Polish Commissioner for Human Rights, VII.562.1.2018.KD, Warsaw 2018, https://www.rpo.gov.pl/sites/default/files/Pismo\%20RPO\%20do\%20Ministerstwa\%20Cyfryzacji.pdf [access: 28.03.2020].
} 
7. Number of social media users worldwide from 2010 to 2021, Statista - The statistic portal, https://www.statista.com.

8. WHO announces COVID-19 outbreak a pandemic, World Health Organization Regional Office for Europe, http://www.euro.who.int.

9. Krzyżanowska A., Prokuratorowi można zarzucić, że nie zna prawa. Trzeba to jednak czynić z taktem, Rzeczpospolita, 2020, https://www.rp.pl.

10. Cambridge Dictionary, https://dictionary.cambridge.org. 